\section{UN ESPACIO ANTIGUO \\ EN LA CAPTURA DIGITAL}

\author{
AN OLD SPACE IN \\ THE DIGITAL CAPTURE
}

Alejandro Pinzón Fotógrafo y realizador de cine y televisión de la Universidad Nacional de Colombia. Profesor del programa de Realización audiovisual, Facultad de Ciencias de la Comunicación, Uniminuto, Bogotá
El cambio de siglo impuso la tecnología digital en la captura de imágenes al reunir todos los procesos que antes costaban tiempos prolongados. El formato digital es ideal para esta época de la inmediatez, pero aquellos que se negaron a usar del todo la tecnología de los bits han protegido un hecho histórico: la fotografía análoga. Ahora se reconoce su alta calidad s como el rigor, la educación estética y la seguridad.

Las primeras fotografías de la sección de $A r$ tefactos son de Juan Carlos Murcia, paisajista y docente universitario. Las imágenes son capturas análogas de medio formato, negativo color, y posterior escaneo digital. Las técnicas análogas y digitales se combinan.

La segunda serie de fotografías fueron hechas por estudiantes de la tecnología en Realización audiovisual en el curso Fotografía digital. La clase empieza con un recorrido por la fotografía análoga y ella se analiza el comportamiento de la luz y su uso, base fundamental para entender la captura actual de imágenes. Todas . gro, color $35 \mathrm{~mm}$.

La tercera serie son capturas en $35 \mathrm{~mm}$, negativo color, blanco y negro y escaneadas para difundirse. El sentido de las imágenes es la dualidad: cada imagen se complementa para crear un sentido y una narrativa. 


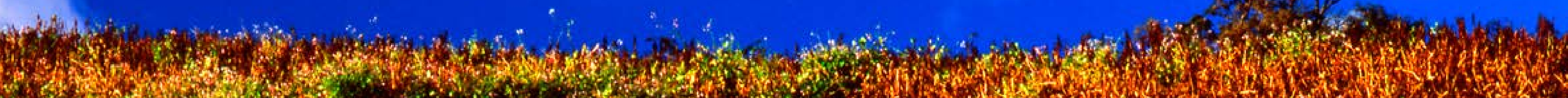

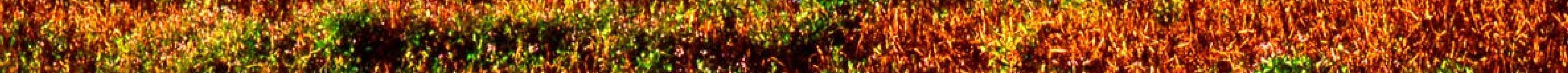




$$
\begin{aligned}
& \text { (3) } \\
& 5=-1 \\
& \text { 4his }=
\end{aligned}
$$$$
\text { 4. }
$$

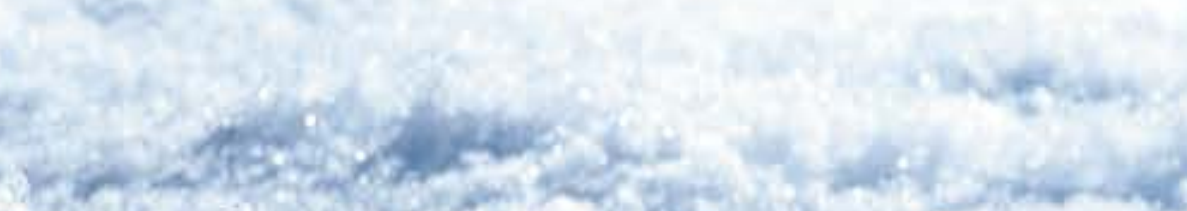

W.

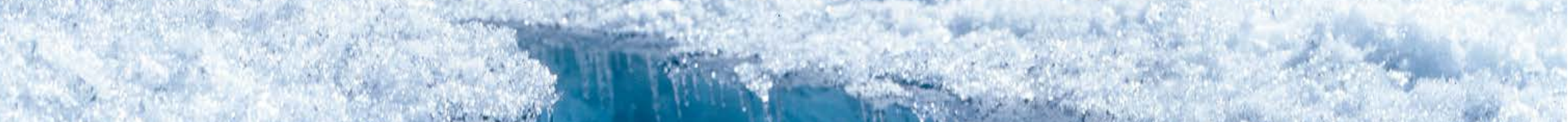

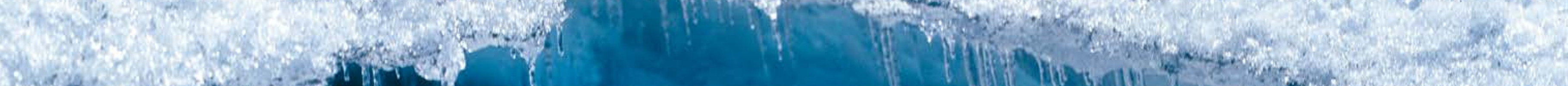

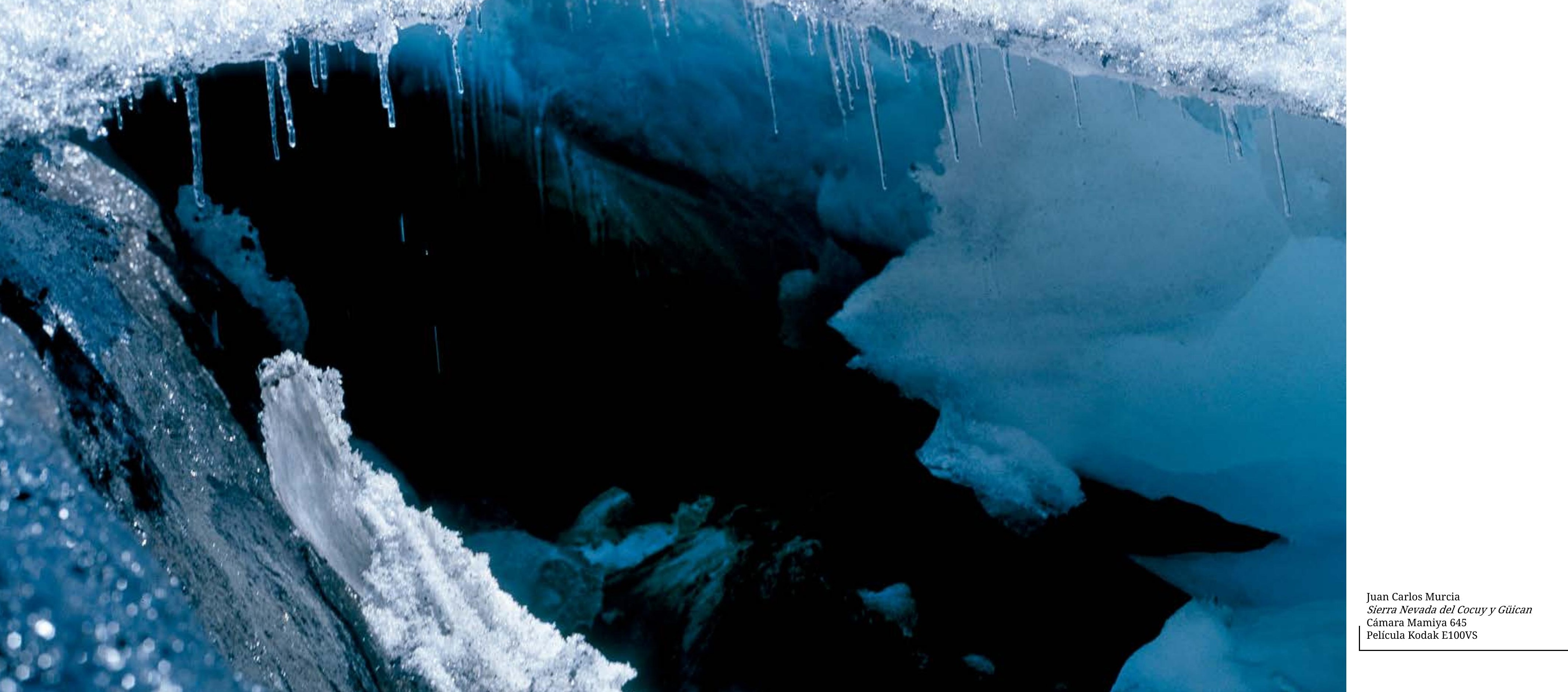




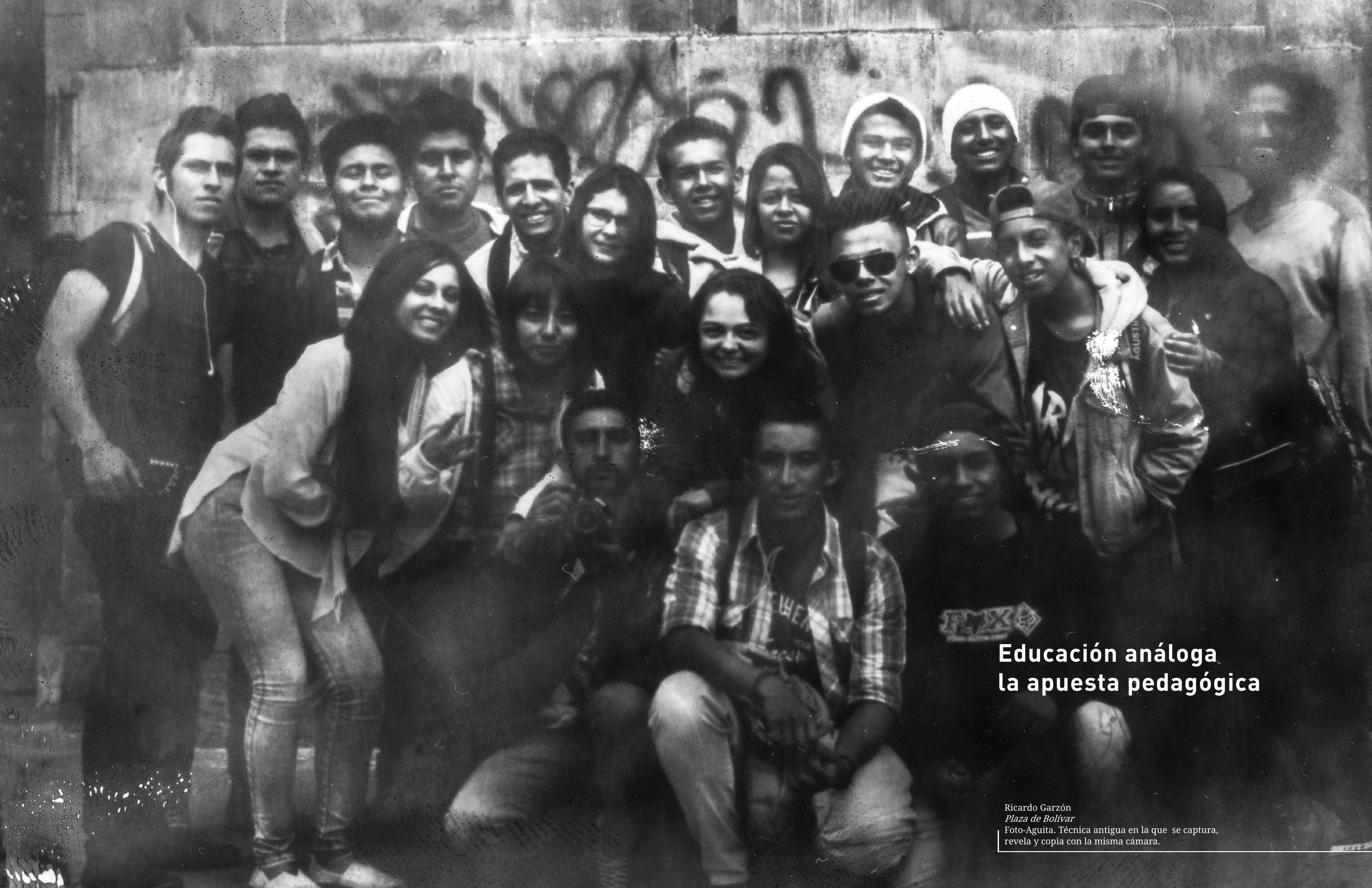









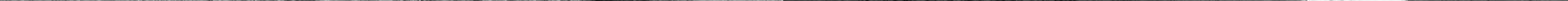




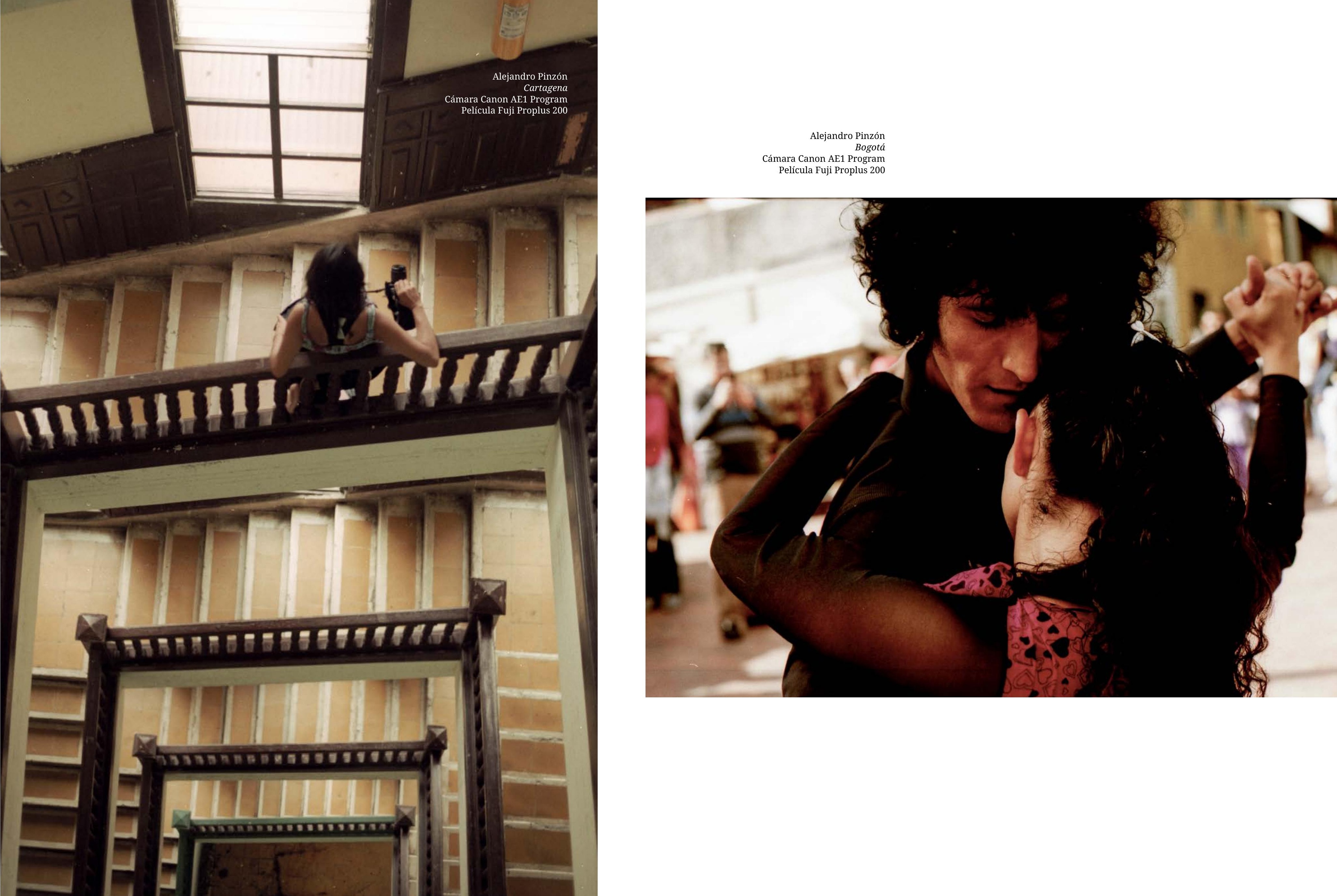

